\title{
ANALYSIS OF THE INTERNET COMMUNICATION MEASURES USED BY ACCOMODATION FACILITIES IN THE CZECH REPUBLIC
}

\author{
[Analýza internetových komunikačních nástrojů ubytovacích kapacit v České \\ republice]
}

\author{
Jitka Novotová ${ }^{1}$ \\ ${ }^{1}$ Technická univerzita v Liberci, Ekonomická fakulta, Voroněžská 13, 46001 Liberec1 \\ E-mail: jitka.novotoval@tul.cz
}

\begin{abstract}
This article is about the accommodation capacities implementation progress regarding their use of on-line communication measures. The tested businesses are from the North Bohemian region. A questionnaire based survey was done with the sample of 342 accommodation facilities. The results show that the average number of on-line communication tools being used in an accommodation capacity is 5,5. It was found out that hotels use the highest number of on-line communication tools and that there is a correlation between the number of communication tools, which are used, and the facility capacity. In the next part the research focused on social media. The contemporary biggest social network is Facebook followed by YouTube. Though, the accommodation facilities are not very active on social networks. $46 \%$ of respondents submit new posts once in a month at maximum. On the other hand, $66 \%$ of respondents agree that social networks are beneficial for them. The conclusion is that social networks have business potential, which is not being fully utilized.
\end{abstract}

Keywords: accommodation, Facebook, Instagram, on-line communication tools, Twitter, YouTube.

JEL classification: L83, M31

Doručeno redakci: 31.5.2018; Recenzováno: 11.6.2018; 15.6.2018; Schváleno k publikování: 19.9.2018

\section{Úvod}

Oblast cestovního ruchu, která zahrnuje rovněž ubytovací kapacity, je v současnosti jednou $\mathrm{z}$ nejsledovanějších priorit v Evropské unii. Hranice v unii jsou otevřeny, lidé mohou svobodně cestovat za nákupy, za prací či za poznáním. Díky tomu se zvyšuje potřeba krátkodobého ubytování a celý segment se tak stává velice důležitým pro ekonomiky jednotlivých zemí Šamborská, aj. (2016). Rozvoj cestovního ruchu sice přináší ubytovacím kapacitám př́ležitost $\mathrm{k}$ růstu, na druhou stranu ale vytváŕí nebývale konkurenční prostředí. V podmínkách vysoké konkurence se neustále zvyšuje důležitost internetu Ho a Lee (2007). V České republice stoupl počet uživatelů internetu za deset let o více než třetinu. $\mathrm{V}$ roce 2017 se pravidelně připojovalo 6,7 milionu obyvatel starších šestnácti let, což je 76,5 procenta tuzemské populace ${ }^{1}$. S tímto rostoucím počtem uživatelů internetu se také zvyšují výdaje do internetové marketingové komunikace. V roce 2017 se vyšplhal objem finančních prostředků do komunikace na tomto médiu na 23,3 miliardy korun, což bylo o 18 \% více než v předchozím roce 2 .

Internetová marketingová komunikace je pro turistický ruch klíčová, z důvodu potřeby oslovovat potenciální zákazníky z celého globalizovaného světa. Dostat informace o destinaci či ubytovacím zařízení $\mathrm{k}$ zákazníkům je jedním z nejdůležitějších předpokladů úspěchu turismu

\footnotetext{
${ }^{1}$ Zdroj: KUČERA, P., 2017. Počet uživatelů internetu v Česku stoupá, stále jsme však pod evropským průměrem, Hospodářské noviny, [online]. 2017. [vid. 7 května 2018]. Dostupný z: https://byznys.ihned.cz/c1-65673310pocet-uzivatelu-internetu-v-cesku-stoupa-stale-jsme-vsak-pod-evropskym-prumerem.

${ }^{2}$ Sdružení pro internetový rozvoj, 2018. Internetová reklama hlásí rekordní investice za loňský rok: více než 23 miliard korun. Sdružení pro internetový rozvoj. [online]. 2018. [vid. 7 května 2018]. Dostupný z: http://www.spir.cz/internetova-reklama-hlasi-rekordni-investice-za-lonsky-rok-vice-nez-23-miliard-korun.
} 
v současnosti Scott (2009). Kasapi a Koc (2012) identifikovali devět komunikačních kanálů, ze kterých potenciální zákazníci čerpají informace o destinacích a ubytovacích kapacitách. Jedná se o osobní zkušenost, zkušenost přátel a známých, o katalogy a časopisy, o oficiální webové stránky hotelů a destinací, sociální sítě, cestovní kanceláře a agentury, média a jiné informační technologie. Tiago aj. (2015) konstatuje, že v současnosti se informace ohledně cestování získávají převážně na internetu. Osobní kontakt s pracovníkem v cestovní kanceláři začíná být méně častým způsobem získání informací o dovolené. Výzkumem Toh aj. (2011) bylo dokonce zjištěno, že až 80 \% hotelových hostů konkrétního hotelu v USA využilo k vyhledání hotelu internet. Více než polovina všech dotázaných si dokonce prostřednictvím webových stránek hotelu nebo pomocí vyhledávačů ubytování hotelový pokoj rezervovala. Pouze $5 \%$ respondentů zajistilo své ubytování přes cestovní kanceláře. $Z$ těchto výsledků je patrné, že internet je v současnosti klíčovým médiem pro marketingovou komunikaci v cestovním ruchu, potažmo pro ubytovací kapacity, které jsou předmětem tohoto článku. Parets (2002) např́íklad uvádí, že internetová marketingová komunikace je vhodná nejen pro velké ubytovací kapacity, ale vzhledem $\mathrm{k}$ ceně a velice přívětivému klientskému prostředí také pro malé ubytovací kapacity, které na řadu běžných komunikačních nástrojů nemají finanční prostředky.

Tento článek se zabývá identifikací nejpoužívanějších internetových komunikačních nástrojů ubytovacích kapacit v České republice, konkrétně v Libereckém, Královehradeckém a Ústeckém kraji. Hlavním cílem článku je identifikovat nejpoužívanější internetové komunikační nástroje využívané k prvotnímu získání zákazníka (získání povědomí o ubytovací kapacitě a rezervace ubytování) a zjistit, zda jsou ke komunikaci využívány také sociální sítě. Tento hlavní cíl je dekomponován do 6 dílčích cílů a sady výzkumných otázek:

1) Identifikovat internetové komunikační nástroje používané ubytovacími kapacitami k prvnímu kontaktu se zákazníkem.

2) Zjistit, zda je použivaný počet online komunikačních nástrojů závislý na typu ubytovací kapacity a na jeho velikosti.

VO1: Má počet lůžek ubytovací kapacity vliv na počet využívaných internetových komunikačních nástrojů?

VO2: Má typ ubytovací kapacity vliv na počet využívaných internetových komunikačních nástrojů?

3) Zjistit, kolik procent ubytovacích kapacit používá ke své komunikaci sociální sítě.

4) Identifikovat vztah mezi typem ubytovací kapacity a používáním sociálních sítí.

VO3: Má typ ubytovací kapacity vliv na používání sociálních sítí?

5) Identifikovat nejpoužívanější sociální sít' využívanou ubytovacími kapacitami v České republice.

6) Zhodnotit, zda existuje vztah mezi počtem přidaných př́spěvků na sociální sítě a subjektivně hodnocenou efektivností těchto sítí.

VO4: Existuje vztah mezi počtem příspěvků vkládaných na sociální sítě a subjektivně hodnocenou efektivností těchto sítí?

\section{Sociální sítě}

Janouch definuje sociální sítě takto: „Sociální sitě jsou online média, kde je obsah (spolu) vytvářen a sdílen uživateli. Sociální média se nepřetržitě mění tím, jak se mění (přibývá) jejich obsah a také přidáváním mnoha funkci" Janouch (2011, s. 210). Sociální sítě je tedy možno označit za prostředí, kde se setkávají a interagují lidé ve velice rychlém čase a utvářejí tak rozsáhlé virtuální prostředí Lee (2013). Sociální sítě v dnešní době neustále rostou a stávají se tak globálním fenoménem ve všech vyspělých zemích. Díky své velké oblibě mezi nejširší vrstvou veřejnosti se sociální sítě staly velice vyhledávaných marketingovým kanálem. 
Marketing se zde stal precizním, osobním a interaktivním nástrojem pro účinné oslovení zákazníků. Marketingoví manažeři mají jedinečnou př́íležitost k hypertargetingu kampaní, $\mathrm{k}$ zapojení členů komunity do diskuzí ohledně produktů či mohou pracovat s osobními doporučeními např́č existující zákaznickou základnou Shih (2010). Sociální sítě přinášejí možnost zkoumat názory zákazníků na výrobky či služby a zjišt’ovat tak, co si konkrétní cílová skupina myslí a co cítí Sterne (2011). Podle Janoucha jsou sociální sítě místem s „kolektivní moudrostí“, kde názor vytvořený na určitý produkt je většinou pravdivý Janouch (2011).

V oblasti cestovního ruchu hrají sociální sítě nezastupitelnou roli například v rozhodovacím procesu cestovatelů, kteří na sociálních sítích vyhledávají informace o turistických lokalitách či ubytovacích kapacitách Zeng a Gerritsen (2014). Toto tvrzení potvrzuje i další výzkum, ve kterém bylo zjištěno, že tematické stránky na sociálních sítích a jejich obsah (fotografie, videa a komentáře) jsou čím dál populárnější př̌i plánování výletů a cest Xiang, aj. (2015). Yu-Lun Hsu (2012) zkoumal využití sociální sítě Facebook ke komunikaci šesti velkými hotely na Taiwanu. Autor zjistil, že tato marketingová komunikace má pozitivní vliv na obsazenost všech šesti ubytovacích kapacit. Jako nedostatek autor zmiňuje jazykovou bariéru stránek jednotlivých hotelů, které jsou pouze v čínštině, a proto nemohou přilákat zahraniční klientelu. Výzkum provedený v České republice ukázal, že mladí lidé do 30 let nejčastěji hledají informace o dovolené na sociálních sítích (nejčastěji na Facebooku a Instagramu, v minimálním zastoupení na YouTube). Tito mladí zákazníci dokonce využívají Instagram jako inspiraci pro výběr destinace své dovolené. Velice pozitivně hodnotí také sponzorované př́spěvky na Instagramu, které nejsou zásadně odlišné od příspěvků sledovaných uživatelů Malačka a Veselá (2017). Využití sociálních sítí v cestovním ruchu se tedy ukazuje jako vynikající strategické rozhodnutí Zeng a Gerritsen (2014).

V dalším textu budou představeny sociální sítě, které dle výsledků průzkumu autorky článku nejčastěji používají oslovené ubytovací kapacity.

\subsection{Facebook}

Největší sociální sítí na světě je již po řadu let Facebook, který byl založen 1. února 2004 Markem Zuckerbergem, studentem Harvardské univerzity. V roce 2006 byl Facebook otevřen pro širokou veřejnost nad 13 let Treadaway a Smith (2011). Nejnovější údaje o počtu uživatelů na celém světě, kteří se připojují alespoň jednou měsíčně, hovoří o 2 miliardách ${ }^{3}$. Počet českých uživatelů byl v roce 2017 okolo 4,9 milionů, počet lidí, kteří Facebook sledují každý den je již po nějakou dobu konstantní a to 3,7 milionů Čechů 4 .

Na Facebooku si mohou založit profil firmy a tím ho začít využívat jako nástroj marketingové komunikace. Facebook představuje velkou přiležitost jak pro nejmenší rodinné, tak pro velké mezinárodní společnosti s mnohaletou tradicí. Je zde možno využívat celou řadu marketingových komunikačních nástrojů, jako je např́klad „WOM“ (slovo z úst), přímý marketing, PR, virální marketing, reklama, podpora prodeje, guerilla marketing, mobilní marketing a buzz marketing Ungerman (2014). Firmy mohou oslovit fanoušky na své firemní stránce, prostřednictvím zpráv, událostí či placené reklamy Janouch (2011). Pomocí správné komunikace na firemní stránce se dá dokonce budovat pozitivní vztah k propagované značce Shih (2010). Když fanoušek stránky zareaguje na nový př́spěvek na stránce tím, že mu dá

\footnotetext{
${ }^{3}$ KASÍK, P., 2017. Facebook má dvě miliardy aktivních uživatelů měsíčně, technet.idnes. [online]. 2017. [vid. 22 května 2018]. Dostupný z: https://technet.idnes.cz/facebook-ma-dve-miliardy-aktivnich-uzivatelu-mesicnep0i-/kratke-zpravy.aspx?c=A170628_103550_tec-kratke-zpravy_pka.

${ }^{4}$ HUŠKOVÁ, L., 2017. Facebook v ČR sleduje už 4,9 milionů uživatelů. Newsfeed. [online]. 2017. [vid. 22 května 2018]. Dostupný z: https://newsfeed.cz/facebook-v-cr-sleduje-uz-49-milionu-uzivatelu/.
} 
„like“ nebo ho sdílí, tato aktivita se zobrazí na jeho soukromé zdi. Díky tomu tento příspěvek vidí jeho přátelé, př́íspěvek se tedy velice rychle a zdarma šírí Facebookem. Toto je jedna z největších výhod Facebooku Kwok a Yu (2013). Další výhodou je fakt, že uživatel nemůže smazáním cookies ve webovém prohlížeči znemožnit cílení reklamy. Uživatelé Facebooku poskytují velké množství osobních údajů, díky kterým se reklama na Facebooku dobře cílí. Díky těmto možnostem je v současnosti Facebook jedním z nejoblíbenějších míst pro marketingovou komunikaci Dempster a Lee (2015).

\subsection{YouTube}

YouTube je největší světovou sítí pro sdílení videí, a tedy druhým největším vyhledavačem po Google. Uživatelé po celém světě zde denně shlédnou až 1,2 miliardy videí. Díky tomuto obrovskému počtu uživatelů je YouTube hojně využíván pro marketingovou komunikaci firem Janouch (2011). Je možné zde využít několik formátů reklamy: obsahovou reklamu, překrývající reklamu, videoreklamu s možností přeskočení, videoreklamu bez možnosti přeskočení a dlouhou videoreklamu bez možnosti přeskočení. Všechny typy reklam jsou založené na systému platby za impresi - CPM (cost per thousand/cost per million). Nejčastěji je v současnosti používána videoreklama s možností přeskočení po pěti vteřinách. Firmy se tedy musí pokusit vytvořit reklamní kampaň, která své hlavní poselství stihne divákovi sdělit za prvních pět vteřin. Od roku 2007 existuje na YouTube Partnerský program, součástí kterého je funkce YouTube Analytics, která shromažd'uje statistiky o výkonnosti videí a reklam Bačíková (2017). Předpokladem úspěšné reklamní kampaně je zobrazování u videa s velkým počtem zhlédnutí. Další možností komunikace je založení firemního kanálu, kde může firma sdílet svá videa o firmě, výrobcích, svých zaměstnancích apod. V tomto případě je klíčovým ukazatelem úspěšnosti kanálu počet odběratelů. Videa z firemních kanálů může kdokoli sdílet na dalších sociálních sítích. Kompatibilní je YouTube hlavně s Facebookem, prostřednictvím něhož se můžou videa velice dobře dále šírit. Video je rovněž možno umístit na blog nebo na vlastní webové stránky. Díky těmto funkcím je YouTube v současnosti velmi vyhledávanou sociální sítí Janouch (2011).

\subsection{Twitter}

Twitter celosvětově používá 328 milionu uživatelů, v České republice se počet odhaduje na 400 tisíc Kasík (2017). Twitter je možno označit za mikroblog, který je využíván ke sdílení krátkých zpráv nazývaných tweety o maximálně 280 znacích. Každý, kdo sleduje pisatele takovéhoto tweetu, si může okamžitě přečíst jeho názor a vyjádřit se $\mathrm{k}$ němu. Informace na Twitteru se proto šírí velkou rychlostí. Žhavé novinky a nejnovější události se jako první často objeví právě na Twitteru, kam je odešle některý z prímých účastníků Lakhani (2010). Tweety se na hlavní stránce řadí podle data, proto je nahoře vždy ten nejaktuálnější př́íspěvek.

Na rozdíl od Facebooku si firma na Twitteru nemůže vytvořit vlastní stránku, ale musí komunikovat prostřednictvím běžného uživatelského účtu. Výhodou Twitteru je jednoduché propojení mezi uživateli. Uživatel pouze klikne na tlačítko sledovat, které je umístěné na profilu jiného uživatele, a automaticky začne odebírat jeho obsah. Do tweetu se dá vložit odkaz na webovou stránku, obrázek či video, ale stejně jako na Instagramu také hashtag. Hashtagy pomohou rozšíriit obsah mezi uživatele, kteři se o daná témata zajímají a také napomáhají vyhledávání Sálová, aj. (2015). Twitter představuje ohromnou virální sílu, která může ovlivnit masy potenciálních zákazníků. Díky tomu tato sociální sít přináší pro oblast marketingu veliký potenciál Rudat a Buder (2015). 


\section{Metodologie}

Pro dosažení výzkumných cílů a výzkumných otázek byl proveden kvantitativní průzkum online nástrojů, které používají ubytovací kapacity ke komunikaci s potenciálními zákazníky, kteří si rezervují ubytování. Účel průzkumu byl deskriptivní a kauzální, cílem tedy bylo popsat současnou situaci v používání online komunikačních nástrojů a identifikovat vztahy mezi vybranými proměnnými. Nejvhodnější metodou sběru dat bylo zvoleno písemné dotazování za pomoci online dotazníku vytvořeného v programu Google Disk, jehož odkaz byl distribuován prostřednictvím emailů. Základním souborem byly stanoveny všechny ubytovací kapacity v Libereckém, Ústeckém a Královéhradeckém kraji, které mají emailovou adresu. Dle databáze Českého statistického úruadu se ve stanovených krajích nachází 2339 ubytovacích zařízení různých typů ${ }^{5}$. Emailový kontakt se podařilo dohledat k 1559 ubytovacím kapacitám, kterým byl následně dotazník rozeslán. $\mathrm{K}$ tomuto kroku bylo přistoupeno $\mathrm{z}$ důvodu předpokládané poměrně nízké návratnosti dotazníků rozesílaných emailem. Literatura udává návratnost dotazníků kolem $20 \%$, často však klesá až k 10 \% Kozel (2011). Email byl adresován majitelům a manažerům ubytovacích zařízení, kteří jsou zodpovědní za marketingovou komunikaci. Dle původního předpokladu byla celková návratnost při počtu 342 odpovědí 22 $\%$.

Data získaná dotazníkovým šetřením byla vyhodnocena ve statistickém programu Statgraphics. Podle druhu proměnných byla použita pro vyhodnocení jednofaktorová analýza rozptylu (ANOVA), test nezávislosti slovních proměnných a korelační analýza. Základní charakteristiky proměnných byly vyhodnoceny pomocí popisné statistiky Vavrek, aj. (2016). ANOVA byla zvolena na základě předpokladu, že hodnotící škály použité v dotazníku jsou kardinální proměnné a také kvůli velkému počtu proměnných v každé výběru, který činil více než 20 . Díky těmto vlastnostem nemusela být ověřována normalita dat Churchill (1987). Druhá podmínka použití analýzy rozptylu, tedy shoda rozptylů, byla ověřována pomocí Bartlettova testu, jehož P-Value musí být větší než 0,05 Hendl (2004).

\subsection{Vzorek respondentů}

Velikost vzorku respondentů na základě návratnosti $22 \%$ byla 342 . Následující tabulka č. 1 ukazuje rozložení ubytovacích kapacit ve vzorku podle jejich typu. Typ ubytovací kapacity stanovuje dokument Svazu podnikatelů ČR ve venkovské turistice a agroturistice na základě směrnice evropské konfederace HOTREC, která zastřešuje ubytovací kapacity na úrovni Evropské unie 6 .

Tabulka 1: Vzorek respondentů a základní soubor dle typu ubytovacích kapacit

\begin{tabular}{|l|l|l|l|l|}
\hline & \multicolumn{2}{|c|}{ Vzorek } & \multicolumn{2}{c|}{ Základní soubor } \\
\hline Typ ubytování & Četnost & Četnost v \% & Četnost & Četnost v \% \\
\hline hotel & 87 & 25 & 566 & 24 \\
\hline penzion & 177 & 52 & 933 & 40 \\
\hline apartmán* & 19 & 6 & 591 & 25 \\
\hline chata $^{*}$ & 39 & 11 & 93 & 4 \\
\hline kemp & 13 & 4 & 156 & 7 \\
\hline turistická ubytovna & 7 & 2 & & \\
\hline
\end{tabular}

Zdroj: vlastní výsledky průzkumu, ČSÚ (2014)

* Apartmány a chaty jsou ČSÚ zařazeny do kategorie ostatních ubytovacích kapacit, kterých je ve zkoumaných krajích dohromady 591.

\footnotetext{
${ }^{5}$ ČSÚ, 2014. Hromadná ubytovací zařízení České republiky. ČSÚ, [online]. 2014, [vid. 31 ledna 2015]. Dostupné z: https://vdb.czso.cz

${ }^{6}$ Asociace hotelů a restaurací České republiky, 2018. Oficiální jednotná klasifikace ubytovacích zařízení České republiky 2015-2020. Hotelstars. [online]. 2018. [vid. 3 května 2018]. Dostupné z: http://www.hotelstars.cz/oficialni-klasifikace-v-cr
} 
Tabulka 2 ukazuje velikost ubytovacích kapacit podle průměrného počtu lůžek a podle mediánu počtu lůžek. Největšími ubytovacími kapacitami jsou kempy, které mají průměrně 101 lůžek (spíše míst pro stany). Druhou největší ubytovací kapacitou jsou podle očekávání hotely a na třetím místě turistické ubytovny.

Tabulka 2: Vzorek respondentů dle velikosti ubytovacích kapacit

\begin{tabular}{|l|l|l|}
\hline \multicolumn{1}{|c|}{ Typ ubytování } & \multicolumn{1}{|c|}{ Průměrný počet lůžek } & \multicolumn{1}{c|}{ Medián počtu lo̊žek } \\
\hline hotel & 85 & 86 \\
\hline penzion & 31 & 25 \\
\hline apartmán & 11 & 10 \\
\hline chata & 23 & 21 \\
\hline kemp & 101 & 110 \\
\hline turistická ubytovna & 42 & 38 \\
\hline
\end{tabular}

Zdroj: vlastní výsledky průzkumu

\section{Výsledky průzkumu}

\subsection{Online komunikační nástroje}

Průzkumem bylo identifikováno 11 internetových komunikačních nástrojů, které ubytovací kapacity využívají ke zvýšení povědomí o své existenci a případně k rezervaci ubytování (tabulka 3). Email má $100 \%$ dotázaných, jelikož to byl předpoklad zařazení ubytovací kapacity do průzkumu. Převážná většina ubytovacích kapacit má rovněž vytvořenou webovou stránku. Sociální sítě se umístily na pátém místě, využívá je 190 dotázaných.

Tabulka 3: Online komunikační nástroje

\begin{tabular}{|c|l|l|l|}
\hline Pořadí & \multicolumn{1}{|c|}{ Online marketingové nástroje } & \multicolumn{1}{c|}{ Četnost $\mathbf{~ \% ~}$} \\
\hline 1 & email & 342 & 100 \\
\hline 2 & Webová stránka & 325 & 95 \\
\hline 3 & Online vyhledávače & 308 & 90 \\
\hline 4 & Online formulář & 239 & 70 \\
\hline 5 & Sociální sítě & 190 & 56 \\
\hline 6 & Online agentury & 185 & 54 \\
\hline 7 & PCC & 109 & 32 \\
\hline 8 & Online PR & 92 & 27 \\
\hline 9 & Online návštěvní kniha & 86 & 25 \\
\hline 10 & Slevové portály & 55 & 16 \\
\hline 11 & skype & 51 & 15 \\
\hline
\end{tabular}

Zdroj: vlastní výsledky průzkumu

Analýzou získaných dat bylo zjišsěno, že průměrný počet internetových nástrojů na ubytovací kapacitu je 5,5. Pomocí korelační analýzy bylo následně zjišt'ováno, jestli existuje vztah mezi kapacitou ubytovacího zařízení (počet lůžek) a počtem používaných nástrojů. Korelační koeficient vyšel 0,287, jde tedy o pozitivní korelaci. Na výzkumnou otázku VO1 je tedy možno odpovědět, že počet lůžek ubytovací kapacity má vliv na počet internetových komunikačních nástrojů, které ubytovací zařízení využívá. Čím větší ubytovací kapacita, tím více nástrojů používá.

Druhá výzkumná otázka VO2 se zaměřila na vliv typu ubytovací kapacity na počet používaných nástrojů. Pro zjišsění odpovědi na tuto výzkumnou otázku byla využita jednofaktorová analýza 
rozptylu (ANOVA), jelikož typ ubytovací kapacity je slovní proměnou. Pro tuto analýzu byla vyřazena kategorie turistická ubytovna $\mathrm{z}$ důvodu velice malého zastoupení ve vzorku respondentů. Tabulka 4 představuje výsledky, ze kterých je patrné, že typ ubytovací kapacity má vliv na počet využívaných komunikačních nástrojů $(\mathrm{P}$-value $=0,02)$. LSD post hoc testem bylo zjištěno, že nejvíce nástrojů mají hotely 6,9 následované kempy, 6,1. Nejmenší počet nástrojů používají chaty 4,9.

Tabulka 4: ANOVA

\begin{tabular}{|l|c|c|c|c|c|c|}
\hline \multicolumn{1}{|c|}{ Source } & Sum of Squares & Df & Mean Square & F-Ratio & P-Value & Bartlett's test \\
\hline Between groups & 51,3772 & 4 & 12,8443 & 3,29 & 0,0137 & \\
\hline Within groups & 445,614 & 334 & 3,9089 & & & \\
\hline Total (Corr.) & 496,992 & 338 & & & & 0,645859 \\
\hline
\end{tabular}

Zdroj: vlastní výsledky průzkumu

\subsection{Sociální sítě}

Jak již bylo zmíněno výše, sociální sítě využívá $56 \%$ dotázaných. Po emailu (100\%), webových stránkách (95\%), online vyhledávačích (90\%) a online formulářích (70\%) se jedná o páté nejpoužívanější internetové médium. Jak jsou sociální sítě využívány různými typy ubytovacích zařizení, ukazuje obrázek 1. Nejčastěji sociální sítě používají hotely a také penziony. Naopak apartmány, chaty a kempy mají účty na sociálních sítích založeny méně často.

Obrázek 1: Používanost sociálních sítí ubytovacími kapacitami

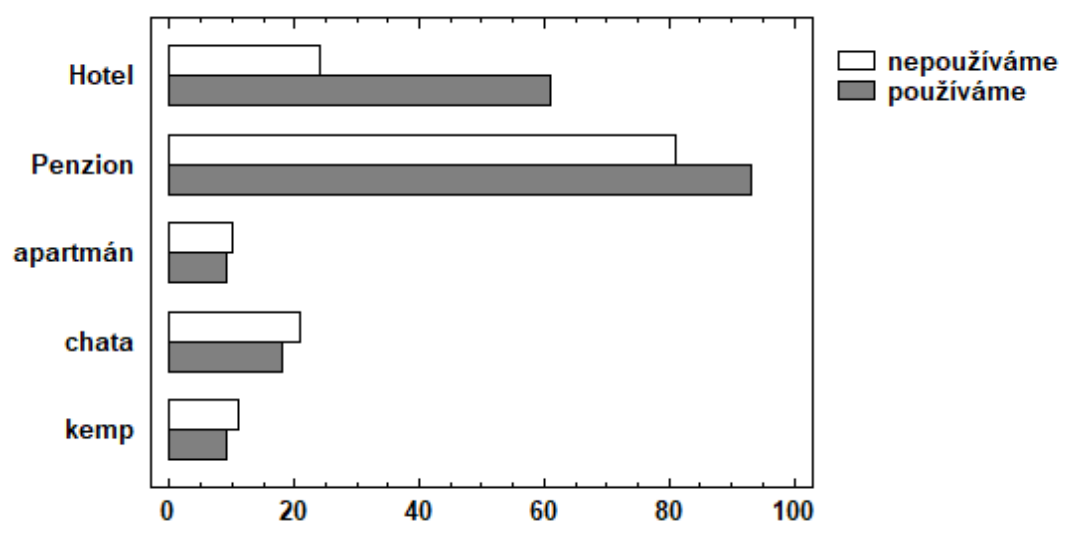

Zdroj: vlastní výsledky průzkumu

Pro zjištění, zda jsou rozdíly v používání sociálních sítí jednotlivými typy ubytovacích kapacit statisticky významné, byl proveden test nezávislosti slovních proměnných. Výsledky ukazují, že typ ubytovací kapacity a používání sociálních sítí je na sobě závislé (Statistic $=12,128$, Pvalue $=0,016$ ). Je možno odpovědět na výzkumnou otázku VO3, že typ ubytovací kapacity má vliv na používání sociálních sítí.

V další části článku budou prezentována pouze data od ubytovacích kapacit, které mají účty na sociálních sítích. Tabulka 5 ukazuje, jaké sociální sítě ubytovací kapacity používají. Z tabulky je patrné, že nejvíce ubytovacích zařízení (180) použivá Facebook. Na druhém místě je YouTube, který využívá pouze 20 dotázaných a na třetím Twitter. Další sociální sítě nejsou ubytovacími kapacitami využívány prakticky nikdy. 
Tabulka 5: Použivání sociálních sítí

\begin{tabular}{|l|l|l|}
\hline \multicolumn{1}{|c|}{ Sociální sít' } & \multicolumn{1}{c|}{ Četnost } & \multicolumn{1}{c|}{ Cetnost v \% } \\
\hline Facebook & 180 & 95 \\
\hline YouTube & 20 & 11 \\
\hline Twitter & 12 & 6 \\
\hline Google+ & 4 & 2 \\
\hline Foursquare & 2 & 1 \\
\hline Instagram & 2 & 1 \\
\hline Pinterest & 2 & 1 \\
\hline
\end{tabular}

Zdroj: vlastní výsledky průzkumu

Facebook je tedy jednoznačnou jedničkou mezi sociálními sítěmi používanými ubytovacími kapacitami. Zajímavým zjišsěním také bylo, že pouze 22 ubytovacích kapacit platí za reklamu na sociálních sítích. Ostatní spoléhají pouze na organické šiřrení svých prŕíspěvků.

Průzkum se dále zaměřil na identifikování četnosti přidávání příspěvků na sociální sítě. Tabulka 6 ukazuje, že pouze $6 \%$ dotázaných přidává na své profily př́spěvky alespoň jednou denně. Nejběžnější frekvence přidávání př́ispěvků je několikrát za měsíc.

Tabulka 6: Frekvence přidávání příspěvků

\begin{tabular}{|l|l|l|l|l|}
\hline \multicolumn{1}{|c|}{ Frekvence přidávání } & Četnost & Četnost v \% & \multicolumn{1}{c|}{$\begin{array}{c}\text { Kumulativní } \\
\text { četnost }\end{array}$} & $\begin{array}{c}\text { Kumulativní četnost v } \\
\text { \% }\end{array}$ \\
\hline Několikrát denně & 2 & 1 & 2 & 1 \\
\hline Denně & 9 & 5 & 11 & 6 \\
\hline Několikrát za týden & 23 & 12 & 34 & 18 \\
\hline Několikrát za měsíc & 67 & 35 & 101 & 53 \\
\hline Jednou za měsíc nebo méně často & 88 & 47 & 189 & 100 \\
\hline
\end{tabular}

Zdroj: vlastní výsledky průzkumu

Tabulka 7 představuje, jak majitelé a manažeři ubytovacích zařízení hodnotí př́ínos sociálních sítí pro jejich podnikání. Hodnocení zahrnuje jak placenou, tak neplacenou formu komunikace. Dle výsledků jsou sociální sítě spíše př́nosné až pro $44 \%$ dotázaných. Na druhou stranu si 10 \% dotázaných myslí, že komunikace na sociálních sítích nemá žádný př́nos a $16 \%$ dotázaných netuší, jestli jsou pro ně sociální sítě př́inosné.

Tabulka 7: Hodnocení přínosu marketingové komunikace na sociálních sítích

\begin{tabular}{|l|l|l|}
\hline \multicolumn{1}{|c|}{ Hodnocení př́ínosu } & Četnost & \multicolumn{1}{|c|}{ Četnost v \% } \\
\hline Velmi přínosné & 23 & 9 \\
\hline Spíše př́nosné & 90 & 35 \\
\hline Občas přínosné & 56 & 22 \\
\hline Spíše nepř́nosné & 18 & 7 \\
\hline Žádný př́nos & 27 & 10 \\
\hline Používáme, ale nevíme jak je př́nosný & 41 & 16 \\
\hline
\end{tabular}

Zdroj: vlastní výsledky průzkumu

Aby mohla být zodpovězena výzkumná otázka VO4, byla provedena korelační analýza mezi proměnnou frekvence přidávání př́spěvků a hodnocením př́nosu sociálních sítí. Korelační koeficient vyšel 0,22 . Můžeme tedy říci, že mezi proměnnými existuje pozitivní vazba. Je možno konstatovat, že existuje vztah mezi počtem př́spěvků vkládaných na sociální sítě a subjektivně hodnocenou efektivností těchto sítí. Marketingoví manažeři ubytovacích kapacit, kteří přidávají příspěvky na sociální sítě častěji, hodnotí sociální sítě jako efektivnější médium než ti, kteří př́íspěvky vkládají méně často. 


\section{Diskuze a závěr}

Hlavním cílem tohoto článku bylo identifikovat nejpoužívanější internetové komunikační nástroje využívané k prvotnímu získání zákazníka a zjistit, zda jsou ke komunikaci využíány také sociální sítě. Průzkum identifikoval šest nejpoužívanějších internetových komunikačních nástrojů a to email, webové stránky firem, online vyhledávače, online formuláře, sociální sítě a online cestovní agentury. Skrze tyto nástroje tedy ubytovací kapacity lákají potenciální zákazníky k rezervaci ubytování. Nejvíce internetových komunikačních nástrojů používají ubytovací kapacity s velkým počtem lůžek. Z tohoto zjištění je patrné, že větší zařízení mohou mít problém s obsazeností, a proto musí své služby intenzivně komunikovat. Počet používaných nástrojů je rovněž závislý na typu ubytovací kapacity. Největší množství komunikačních nástrojů používají hotely a kempy. Právě tyto dva typy ubytování patř́i mezi kapacitně největší. Hotely, které se zúčastnily průzkumu, mají v průměru 85 lůžek a kempy 101. Souhrnně je tedy možno konstatovat, že nejvíce internetových komunikačních nástrojů používají hotely a kempy a to $\mathrm{z}$ důvodu jejich velké kapacity a nutnosti tuto kapacitu naplňovat.

Druhá polovina praktické části článku se zabývala již pouze sociálními sítěmi, které používá $56 \%$ respondentů, nejvíce hotely a penziony. S přehledem nejpoužívanější sociální sítí je Facebook, který používá $95 \%$ ubytovacích kapacit, které komunikují prostřednictvím sociálních sítí. Facebook nabízí firmám řadu možností, jak komunikovat se zákazníky. Základní forma komunikace je zcela zdarma, pro lepší šíření je ovšem nutné si své př́spěvky zaplatit. Od začátku roku 2018 Facebook upravil algoritmus, který tlumí šíření firemních příspěvků mezi uživatele Facebooku. Nově mají dostávat více prostoru př́spěvky od fyzických osob (přátel) než př́spěvky na firemních stránkách. Dopad tohoto opatření v současnosti zkoumá Jitka Ládrová (2018), která porovnala účinnost tř́ totožných reklamních kampaní, které byly směřovány na stejnou cílovou skupinu, a byla za ně zaplacena stejná částka. První sada reklam byla spuštěna v roce 2017 , druhá v roce 2018 po zavedení nového algoritmu. Výsledky ukázaly, že při zachování stejných podmínek byl dosah příspěvků v roce 2017 větší než v roce 2018. To znamená, že reklama se stejným dosahem stojí v roce 2018 až o 34 \% více, než reklama před zavedením nového algoritmu. Algoritmus tedy ovlivňuje nejen organické šíření příspěvků, ale i placenou formu reklamy. Toto je špatná zpráva pro manažery ubytovacích kapacit, kteří jsou změnou značně ovlivněni. Malé podniky nemohou zpravidla dávat do reklamy na Facebooku velké finanční částky a se změnou algoritmu budou muset platit více nebo se jim sníží dosah př́spěvků. Výhodu mají ubytovací kapacity, které jsou na Facebooku již delší dobu, a mají tudíž vybudovanou stabilní fanouškovskou základnu. Za současných podmínek bude stále těžší oslovovat potenciální zákazníky prostřednictvím nově vzniklých firemních stránek.

Druhou nejpoužívanější sociální sítí mezi ubytovacími kapacitami je dle výsledků YouTube a třetí Twitter. Tento výsledek nekoresponduje se zjištěním Malačky a Veselé (2017), které uvádějí, že hlavně mladí lidé hledají informace o dovolené na Facebooku a Instagramu. Přitom účet na Instagramu mají dle výsledků prezentovaného průzkumu pouze 2 ubytovací kapacity. Z výsledků je patrné, že manažeři ubytovacích kapacit ještě nepřišli na to, že Instagram je pro jejich komunikaci vhodným médiem. Manažerům lze doporučit, aby si na Instagramu založili účet, kam mohou vkládat fotografie svého ubytovacího zařízení, fotografie jídel, které vaří v restauraci, ale $\mathrm{i}$ fotografie $\mathrm{z}$ akcí, které ubytovací kapacity pořádají. Zařazením Instagramu do komunikační strategie lze oslovit mladou generaci potenciálních zákazníků. Instagram ovšem není úplně vhodný pro komunikaci s věkovou kategorií nad třicet let, která Instagram zatím př́liš nepoužívá. Rizikem Instagramu pro ubytovací kapacity může být rovněž dlouhodobý nedostatek zajímavého a kvalitního obsahu, který vyústí v malou sledovanost profilu a tedy neúčinnost marketingové komunikace. Předpokladem pro správnou komunikaci je tedy kvalitní obsah a pověřená osoba, která se bude o profil pravidelně starat. 
Posledním dílčím cílem článku bylo zhodnotit, zda existuje vztah mezi počtem přidaných př́spěvků na sociální sítě a subjektivně hodnocenou efektivností těchto sítí. Sociální sítě hodnotí jako efektivní $44 \%$ manažerů. Manažeři nejčastěji na své profily přidávají př́spěvky několikrát měsíčně, pouze $6 \%$ dotázaných přidává př́spěvky jednou denně. Analýzou získaných dat bylo zjištěno, že marketingoví manažeři ubytovacích kapacit, kteří přidávají příspěvky na sociální sítě častěji, hodnotí sociální sítě jako efektivní médium. Z tohoto zjišsění vyplývá, že sociální sítě jsou efektivním médiem v situaci, kdy se na nich pravidelně komunikuje. Problémem velké části ubytovacích kapacit je fakt, že mají sice profily na sociálních sítích založeny, ale nedostatečně je využívají. V př́ípadě nízké frekvence přidávání příspěvků jsou jejich firemní stránky prakticky mrtvé a neslouží k předem stanovenému cíli oslovování zákazníků.

Na základě zjištěných poznatků lze ubytovacím kapacitám doporučit využívat internetové komunikační nástroje, zejména sociální sítě Facebook a Instagram. Jestliže se manažeři ubytovací kapacity rozhodnou profil na sociální síti založit, musí zajistit pravidelné přidávání obsahu a správu fïremní stránky. Zvláště v poslední době, kdy Facebook zpř́ísňuje podmínky šíření příspěvků, je pravidelná a kvalitní komunikace základním předpokladem úspěšné komunikační kampaně ubytovacích kapacit.

\section{Literatura}

[1] Asociace hotelů a restaurací České republiky, 2018. Oficiální jednotná klasifikace ubytovacích zařízení České republiky 2015-2020. Hotelstars. [online]. 2018. [vid. 3 května 2018]. Dostupné z: http://www.hotelstars.cz/oficialni-klasifikace-v-cr

[2] BAČÍKOVÁ, Z., 2017. Sociální média, In: J. SVĚTLÍK ed. Reklama: teorie, koncepce, modely. Rzeszow: WSIZ Rzeszow. ISBN 978-83-64286-71-1.

[3] ČSÚ, 2014. Hromadná ubytovací zařízení České republiky. ČSÚ, [online]. 2014, [vid. 31 ledna 2015]. Dostupné z: https://vdb.czso.cz

[4] DEMPSTER, C. and J. LEE, 2015. The Rise of the Platform Marketer: Performance Marketing with Google, Facebook, and Twitter, Plus the Latest High-Growth Digital Advertising Platforms. Hoboken, NJ: John Wiley \& Sons, Inc. ISBN: 978-1-119-05972-1.

[5] HENDL, J., 2004. Přrehled statistických metod zpracování dat. Praha: Portál. ISBN 807178-820-1.

[6] HO, C. I. and Y. L. LEE, 2007. The development of an e-travel service quality scale. Tourism Management. 28(6), 1434-1449. ISSN 0261-5177.

[7] HSU, Y. L., 2012. Facebook as international eMarketing strategy of Taiwan hotels. International Journal of Hospitality Management, 31(3), 972-980. ISSN 0278-4319.

[8] HUŠKOVÁ, L., 2017. Facebook v ČR sleduje už 4,9 milionů uživatelů. Newsfeed. [online]. 2017. [vid. 22 května 2018]. Dostupný z: https://newsfeed.cz/facebook-v-crsleduje-uz-49-milionu-uzivatelu/.

[9] CHURCHILL, G. A., 1987. Marketing research: Methodological Foundations, 4 ed. Chicago: Dryden, 1987. ISBN 0-03-005532-6.

[10] JANOUCH, V., 2011. Internetový marketing. Brno: Computer Press. ISBN 978-80-2512795-7. 
[11] KASAPI, I. and M. KOC, 2012. Changing Tourism Consumer Behavior: The Impacts on Tourism Demand in Albania. Creative and Knowledge Society, 2(2), 16-34. ISSN 13385283.

[12] KASÍK, P., 2017. Facebook má dvě miliardy aktivních uživatelů měsíčně, technet.idnes. [online]. 2017. [vid. 22 května 2018]. Dostupný z: https://technet.idnes.cz/facebook-madve-miliardy-aktivnich-uzivatelu-mesicne-p0i-/kratkezpravy.aspx?c=A170628_103550_tec-kratke-zpravy_pka.

[13] KOZEL, R., L. MYNÁŘOVÁ a H. SVOBODOVÁ, 2011. Moderní metody a techniky marketingového výzkumu, Praha: Grada Publishing. ISBN 978-80-247-3527-6.

[14] KUČERA, P., 2017. Počet uživatelů internetu v Česku stoupá, stále jsme však pod evropským průměrem, Hospodářské noviny, [online]. 2017. [vid. 7 května 2018]. Dostupný z: https://byznys.ihned.cz/c1-65673310-pocet-uzivatelu-internetu-v-ceskustoupa-stale-jsme-vsak-pod-evropskym-prumerem.

[15] KWOK, L. and B. YU, 2013. Spreading social media messages on facebook: an analysis ov restaurant business-to-consumer communications. Cornell Hospitality Quarterly, 54(1), 84-94. ISSN 1938-9663.

[16] LÁDROVÁ, J., 2018. New Facebook algorithm: How does it affect sponsored posts? In: DOUČEK Petr (ed.). Proceedings of the 26 th Interdisciplinary Information Management Talks: IDIMT. Trauner Verlag. s. 225-230. ISBN 978-3-99062-339-8.

[17] LAKHANI, D., 2010. Jak prodávat, když nikdo nekupuje, Praha: Grada, ISBN 978-80247-3309-8.

[18] LEE, D. Y., 2013. The role of attachment style in building social capital from a social networking site: The interplay of anxiety and avoidance. Computers in Human Behavior, 29(2013), 1499-1509. ISSN 0747-5632.

[19] MALAČKA, L. and J. VESELÁ, 2017. Consumer behaviour of the travel agencies' customers in the segment of seaside holiday. Acta academica karviniensia, 17(4), 69-76. ISSN 2533-7610.

[20] PARETS, R. T., 2002. Getting the word out: profiting from smart Internet marketing isn't just for the big boys. Lodging Magazine, 37-38. ISSN 0360-9235.

[21] RUDAT, A. and J. BUDER, 2015. Making retweeting social: The influence of content and context information on sharing news in Twitter. Computers in Human Behavior, 46(May 2015), 75-84. ISSN 0747-5632.

[22] SÁlOVÁ, A., aj., 2015. Copywriting: Pište texty, které prodávají. Brno: Computer Press. ISBN: 978-80-251-4589-0.

[23] SCOTT, M., 2009. Marketing communications in tourism and hospitality. Oxford: Butterworth-Heinemann. ISBN 978-0-7506-8277-0.

[24] Sdružení pro internetový rozvoj, 2018. Internetová reklama hlásí rekordní investice za loňský rok: více než 23 miliard korun. Sdružení pro internetový rozvoj. [online]. 2018. [vid. 7 května 2018]. Dostupný z: http://www.spir.cz/internetova-reklama-hlasi-rekordniinvestice-za-lonsky-rok-vice-nez-23-miliard-korun.

[25] SHIH, C., 2010. Vydělávejte na facebooku. Brno: Computer Press. ISBN 978-80-2512833-6.

[26] STERNE, J., 2011. Měrime a optimalizujeme marketing na sociálních sitích, Brno: Computer Press. ISBN 978-80-251-3340-8. 
[27] ŠAMBORSKÁ, K., D. MATUŠÍKOVÁ, A. ŠENKOVÁ, and J. MITRÍKOVÁ, 2016. Comparison of tourism performance in chosen european countries with the accent to Slovak republic in the period before and after accession to European union membership at the beginning of $21^{\text {th }}$ century. Ecoforum, 5(1), 107-114. ISSN $2344-2174$.

[28] TIAGO, M.T.P.M.B., aj., 2016. Baby boomers turning grey: European profiles. Tourism Management. 54(June 2016), 13-22. ISSN 0261-5177.

[29] TOH, R. S., Ch. F. DEKAY and P. RAVEN, 2011. Travel planning: searching for and booking hotels on the internet. Cornell Hospitality Quarterly, 52(4), 388-398. ISSN: 19389655.

[30] TREADAWAY, CH. a M. SMITH, 2011. Marketing na Facebooku. Brno: Computer Press. ISBN 978-80-251-3337-8.

[31] UNGERMAN, O., 2014. Využití sociálních médií malými a střednimi podniky $v$ komunikaci se spotréebitelem. Liberec: Technická univerzita v Liberci. ISBN 978-80-7494157-3.

[32] VAVREK, R., M. JUSKOVÁ and L. BEDNÁŘOVÁ, 2016. Correlations between selected macroeconomic indicators - case study of Slovak Republic and Czech Republic. In: SGEM, ed. International Multidisciplinary Scientific Conferences on Social Sciences and Arts, Bulgaria. s. 793-798. ISBN 978-619-7105-74-2.

[33] XIANG, Z., aj., 2015. Adapting to the Internet: Trends in Travelers' Use of the Web for Trip Planning: Trends in Travelers' Use of the Web for Trip Planning. Journal of Travel Research, 54(4), 511-527. ISSN 00472875.

[34] ZENG, B. and R. GERRITSEN, 2014. What do we know about social media in tourism? Tourism Management Perspectives, 10(April 2014), 27-36. ISSN 2211-9736. 